\title{
A case of damage to a peritoneal dialysis tubing by a pet cockatoo and review of the literature
}

Toshihide Naganuma*, Yoshiaki Takemoto, Junji Uchida and Tatsuya Nakatani

\begin{abstract}
Background: Peritoneal dialysis (PD) access is important for patients undergoing PD. However, one of the potential complications of peritoneal dialysis access is damage to the dialysis tubing. Although most dialysis tubing damage is due to human error, there have been reports of damages attributed to pets owned by the patients. Much of the damage caused by pets has been attributable to cat biting or scratching, whereas the present case is an extremely rare case of dialysis tubing damage caused by a pet cockatoo.

Case presentation: A 65-year-old male with end-stage renal disease due to diabetic nephropathy who had been undergoing continuous ambulatory peritoneal dialysis (CAPD) for 6 years was admitted to our hospital with the chief complaint of dialysis tubing damage. While the patient was playing with his pet cockatoo on his belly after taking it out of its cage, the bird bit into his dialysis tubing of his transfer set without him realizing it, thus damaging the tube. The patient noticed that his dialysis tubing was leaking and realized that it had been damaged. He folded the end of the damaged tube, secured it with a rubber band to prevent further leakage, and made an emergency visit to our hospital. Upon inspection, we found that the dialysis tubing was completely disconnected, $28 \mathrm{~cm}$ from the metal connector of the connection tube. After consultation, the damaged tube was replaced. As a preventive measure for peritonitis, antibiotics were administered orally for 1 week (oral levofloxacin, 250 mg every $48 \mathrm{~h}$ ). The patient was instructed to be careful when handling his cockatoo, and his CAPD treatment has been continued without incident to date.
\end{abstract}

Conclusion: This is a rare case report of PD tubing damage caused by a cockatoo kept at home. It may be necessary to pay sufficient attention to PD equipment damage by birds in PD patients keeping large birds, such as cockatoos.

Keywords: Peritoneal dialysis, Dialysis tubing, Damage, Pet, Bird, Cockatoo

\section{Background}

Peritoneal dialysis (PD) access is important for patients undergoing PD, just as vascular access is important for hemodialysis patients. However, one of the potential complications of peritoneal dialysis access is damage to the PD equipment including dialysis tubing. Although most dialysis tubing damage is due to human error, there have been reports of damages attributed to pets owned by the patients [1-18]. Damage to the dialysis tubing is usually discovered by dialysate leakage, but dialysis tubing damage has also been revealed after examining the

\footnotetext{
* Correspondence: spxd48k9@aria.ocn.ne.jp

Department of Urology, Osaka City University Medical School, 1-4-3

Asahi-machi, Abeno-ku, Osaka 545-8585, Japan
}

cause of peritonitis. As such, while many of the damages brought about by pets have been attributable to cat biting $[1-10,13,14,16-18]$, our present case was an extremely rare case of dialysis tubing damage caused by a pet cockatoo.

\section{Case presentation}

A 65-year-old male with end-stage renal disease due to diabetic nephropathy who had been undergoing continuous ambulatory peritoneal dialysis (CAPD) for 6 years was admitted to our hospital with the chief complaint of dialysis tubing damage. One Sunday night, while exchanging the dialysate, the patient took his pet cockatoo out of the cage and let it play on his belly, but the bird bit and cut the dialysis tubing without this being noticed by

(C) The Author(s). 2018 Open Access This article is distributed under the terms of the Creative Commons Attribution 4.0 International License (http://creativecommons.org/licenses/by/4.0/), which permits unrestricted use, distribution, and 


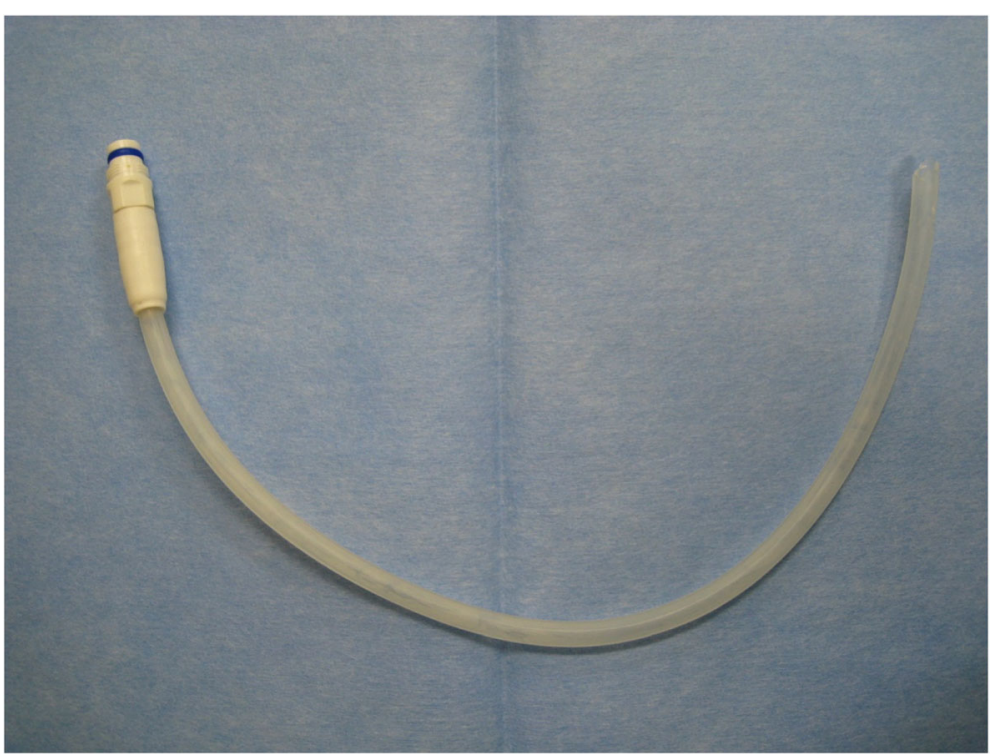

Fig. 1 Cut peritoneal dialysis tubing (entire view)

the patient. He became aware of an abnormality when he noticed leakage of dialysate and then found that the tube was cut. He folded the end of the damaged tube, secured it with a rubber band to prevent further leakage, and visited the emergency room of our hospital about 30 min after the damage occurred.

Upon inspection, we found that the tube was completely disconnected, $28 \mathrm{~cm}$ from the metal connector of the connection tube (Figs. 1 and 2). At that time, his blood pressure was $130 / 80 \mathrm{mmHg}$, heart rate $72 / \mathrm{min}$ with regular rhythm, and temperature $36.8^{\circ} \mathrm{C}$. He was lucid, and his abdomen was soft and flat and had no tenderness. Laboratory findings revealed a white blood cell count of $4700 / \mu \mathrm{L}$, hemoglobin of $8.9 \mathrm{~g} / \mathrm{dl}$, a platelet count of $168 \times 10^{3} / \mu \mathrm{l}$, and a $\mathrm{C}$-reactive protein level of $0.21 \mathrm{mg} / \mathrm{dL}$.

After consultation, the damaged tube was replaced. Since the patient was treated at the nighttime emergency room, a blood cell count in the dialysate and a culture of the dialysate and damaged catheter were not performed. As a preventive measure for peritonitis, antibiotics were administered orally for 1 week (oral levofloxacin, $250 \mathrm{mg}$ every $48 \mathrm{~h}$ ). The patient was advised to revisit the hospital if he had fever or abdominal pain before his regular

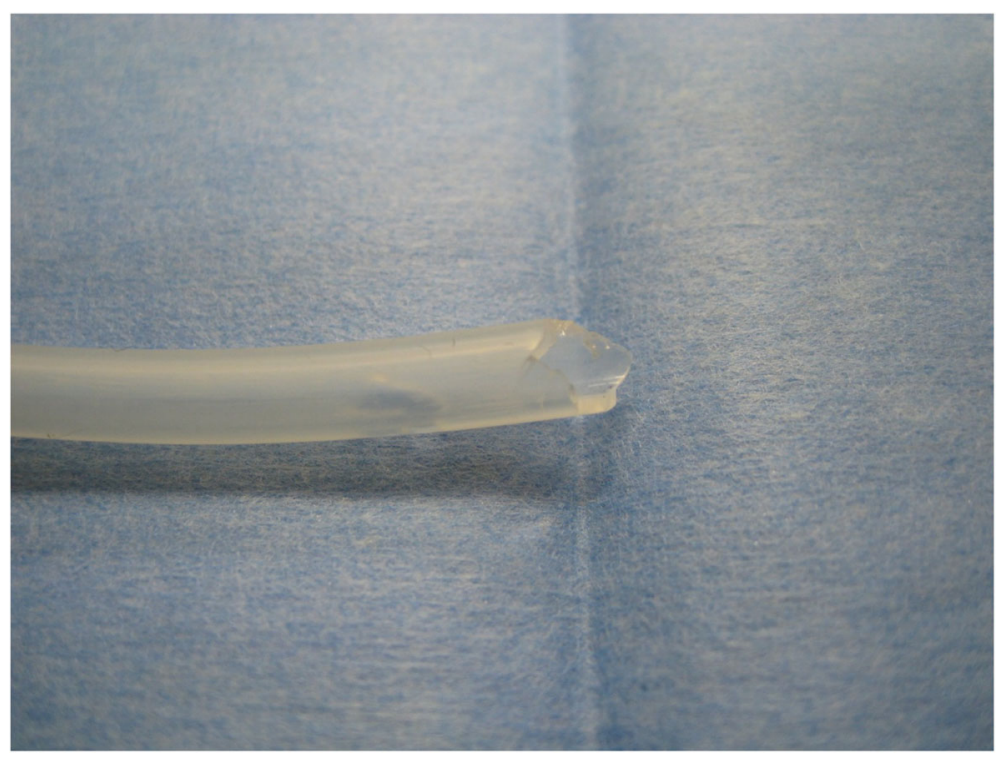

Fig. 2 Cut surface of the tubing 
Table 1 Reports of damage to PD equipment caused by animals

\begin{tabular}{|c|c|c|c|c|c|c|c|c|}
\hline Case & References & $\begin{array}{l}\text { Year } \\
\text { reported }\end{array}$ & $\begin{array}{l}\text { Age }(y) / \\
\text { sex }\end{array}$ & PD type & $\begin{array}{l}\text { Animal } \\
\text { exposure }\end{array}$ & $\begin{array}{l}\text { State of damage of PD } \\
\text { equipment }\end{array}$ & Peritonitis & Culture results \\
\hline 1 & Paul et al. [1] & 1987 & $55 / F$ & CCPD & Cat & Dialysis tubing punctured & + & Pasteurella multocida \\
\hline 2 & London et al. [2] & 1991 & $54 / \mathrm{M}$ & CCPD & Cat & Dialysis tubing punctured & + & Pasteurella multocida \\
\hline 3 & Makin et al. [3] & 1991 & $39 / M$ & CAPD & Cat & Dialysis tubing punctured & + & Neisseria pharyngis \\
\hline 4 & Makin et al. [3] & 1991 & $58 / F$ & CAPD & Cat & Dialysis tubing punctured & - & Staphylococcus hominis \\
\hline 5 & Makin et al. [3] & 1991 & $73 / \mathrm{M}$ & CAPD & Cat & Dialysis tubing punctured & - & Sterile \\
\hline 6 & Makin et al. [3] & 1991 & $24 / F$ & CAPD & Cat & Dialysis tubing punctured & - & Sterile \\
\hline 7 & Kitching et al. [4] & 1996 & $75 / \mathrm{M}$ & CAPD & Cat & Dialysis tubing punctured & + & Pasteurella multocida \\
\hline 8 & Uribarri et al. [5] & 1996 & $42 / F$ & CCPD & Cat & Dialysis tubing punctured & + & Pasteurella multocida \\
\hline 9 & Loghman et al. [6] & 1997 & $12 / F$ & CCPD & Cat & Dialysis tubing punctured & + & Pasteurella multocida \\
\hline 10 & Joh et al. [7] & 1998 & $55 / \mathrm{M}$ & CCPD & Cat & Dialysis tubing punctured & + & Pasteurella multocida \\
\hline 11 & Chadha et al. [8] & 1999 & $18 / \mathrm{M}$ & CCPD & Cat & Dialysis tubing punctured & + & $\begin{array}{l}\text { Capnocytophaga } \\
\text { canimorsus }\end{array}$ \\
\hline 12 & Hamai et al. [9] & 1999 & 49/M & CCPD & Cat & Dialysis tubing punctured & + & $\begin{array}{l}\text { Enterobacter agglomerans, } \\
\text { Pasteurella multocida, alpha- } \\
\text { Streptcoccus }\end{array}$ \\
\hline 13 & $\begin{array}{l}\text { Van Langenhove et } \\
\text { al. [10] }\end{array}$ & 2000 & $22 / F$ & CCPD & Cat & Dialysis tubing punctured & + & Pasteurella multocida \\
\hline 14 & Campos et al. [11] & 2000 & $8 / \mathrm{M}$ & CCPD & Hamster & Dialysis tubing punctured & + & Pasteurella pneumotropica \\
\hline 15 & Freeman et al. [12] & 2004 & $14 / F$ & Unknown & Hamster & $\begin{array}{l}\text { Peritoneal catheter } \\
\text { punctured }\end{array}$ & + & Pasteurella aerogenes \\
\hline 16 & Mat et al. [13] & 2005 & $52 / \mathrm{M}$ & CCPD & Cat & Dialysis tubing punctured & + & Pasteurella multocida \\
\hline 17 & Malik et al. & 2005 & $21 / F$ & CCPD & Cat & Dialysis tubing punctured & + & Pasteurella multocida \\
\hline 18 & Malik et al. & 2005 & $58 / \mathrm{M}$ & CCPD & Cat & Dialysis tubing punctured & + & Pasteurella multocida \\
\hline 19 & Sedlacek et al. [15] & 2008 & $57 / F$ & CCPD & Cockatoo & Dialysis tubing punctured & + & Mucor species \\
\hline 20 & $\begin{array}{l}\text { Rondon-Berrios et al. } \\
\text { [16] }\end{array}$ & 2010 & $38 / \mathrm{M}$ & CCPD & Cat & Dialysis tubing punctured & + & Pasteurella multocida \\
\hline 21 & Nishina et al. [17] & 2012 & $45 / M$ & CCPD & Cat & PD solution bag punctured & + & Pasteurella multocida \\
\hline 22 & Giron et al. [18] & 2017 & $72 / \mathrm{M}$ & CCPD & Cat & Dialysis tubing punctured & + & $\begin{array}{l}\text { Pasteurella multocida } \\
\text { and Streptcoccus canis }\end{array}$ \\
\hline 23 & Present case & 2018 & $65 / M$ & CAPD & Cockatoo & Dialysis tubing cut & - & NA \\
\hline
\end{tabular}

visit 1 month later, but he did not suffer from peritonitis during that time. The patient was instructed to be careful when handling his cockatoo, and his CAPD treatment has been continued without incident to date.

\section{Discussion}

Damage to PD equipment can often occur due to human error. However, PD equipment damage caused by pets in PD patients has recently been occasionally reported, with an increase in the number of families keeping pets [1-18]. As described above, the causative pet was a cat in almost all cases, other than two cases caused by a hamster [11, 12], and one case caused by a cockatoo [15] (Table 1). To our knowledge, this is the second case report of PD tubing damage by a bird.

The PD equipment damaged by pets was dialysis tubing in most reported cases. One case each of PD catheter damage and PD solution bag damage has also been reported (Table 1). The type of PD in patients whose equipment was damaged was continuous cycler peritoneal dialysis in many cases (Table 1), suggesting that animals frequently bit or scratched the equipment which remained unnoticed by the patient, i.e., during sleep. Damage to PD tubing by pets does not completely tear the tube (Table 1 ), but results in a pinhole-shaped damage that may go unnoticed until leakage of PD solution is confirmed, and discovery may be delayed when the leakage is minor. In our case, the cockatoo completely cut the dialysis tubing with its beak in front of the patient during CAPD operation. Thus, the patient noticed the damage immediately and visited our hospital. Early treatment including antibiotic administration may have prevented peritonitis.

Very little epidemiological data are available on pet-related peritonitis in peritoneal dialysis. Incidences 
of $0.54 \%$ in all PD peritonitis cases in a report on a French-speaking registry for peritoneal dialysis (RDPLF) and of $0.03 \%$ in all cases of PD peritonitis in a single-center study have been reported [19]. In general, PD equipment damage can be a cause of PD peritonitis, but bacteria not observed in normal peritonitis are often detected in PD peritonitis caused by pets (Table 1), due to differences in bacterial flora between pets and humans [19-21]. In cats and dogs, Pasteurella species, which are indigenous bacteria in the oral cavity, are problematic as causative bacteria of peritonitis [19, 21]. As shown in Table 1, the culture results were Pasteurella species in most previous reports with a cat. Chlamydia psittaci infection is a well-known Cockatoo-associated infection [22], and generally, birds may cause fungal infection because many fungi are found on the feathers and skin of healthy birds [20]. Among these, Cryptococcus neoformans is well-known and causes pulmonary and skin cryptococcosis [20, 23]. Fungal infection of PD patients caused by birds has rarely been reported, but an outbreak of Candida parasilosis-induced fungal peritonitis that was considered to have been caused by pigeon guano has been described [24]. Mucormycosis peritonitis that was likely to have been caused by a cockatoo has also been reported in a case involving biting of PD tubing by a cockatoo [15], similarly to our case. Our patient received preventive drug administration of levofloxacin because the presence or absence of infection was unclear at the time of arrival and this drug is effective for both Chlamydia psittaci and contaminating bacteria.

In conclusion, this is the first case report of PD tubing damage without peritonitis caused by a cockatoo kept at home. However, only cases in which peritonitis develops tend to be reported. Thus, there actually may be more cases of PD equipment damage by pets. Therefore, it may be necessary to pay attention to $\mathrm{PD}$ equipment damage by birds in PD patients keeping large birds, such as cockatoos, that have powerful beaks and are playful because of their high intelligence.

\section{Abbreviations}

CAPD: Continuous ambulatory peritoneal dialysis; CCPD: Continuous cycler peritoneal dialysis; F: Female; M: Male; NA: Not available; PD: Peritoneal dialysis

\section{Acknowledgements}

Not applicable.

\section{Funding}

The authors declare that there is no funding related to this manuscript.

Availability of data and materials

The data and materials were all included in the manuscript.

\section{Authors' contributions}

All the authors have approved the manuscript and agree with the submission to the esteemed journal. YT provided the discussion and treatment of the patient. JU collected the data and wrote the manuscript. TN reviewed and revised the manuscript. All authors read and approved the final manuscript.

\section{Ethics approval and consent to participate}

Written informed consent was obtained from the patient for the publication of this case report.

\section{Consent for publication}

For the publication of this case report, written agreement was obtained from the patient.

\section{Competing interests}

The authors declare that they have no competing interests.

\section{Publisher's Note}

Springer Nature remains neutral with regard to jurisdictional claims in published maps and institutional affiliations.

Received: 2 May 2018 Accepted: 8 November 2018

Published online: 16 November 2018

\section{References}

1. Paul RV, Rostand SG. Cat-bite peritonitis: Pasteurella multocida peritonitis following feline contamination of peritoneal dialysis tubing. Am J Kidney Dis. 1987;10(4):318-9.

2. London RD, Bottone EJ. Pasteurella multocida: zoonotic cause of peritonitis in a patient undergoing peritoneal dialysis. Am J Med. 1991;91(2):202-4.

3. Makin AJ, Cartwright KA, Banks RA. Keeping the cat out of the bag: a hazard in continuous ambulatory peritoneal dialysis. BMJ. 1991;303(6817):1610-1.

4. Kitching AR, Macdonald A, Hatfield PJ. Pasteurella multocida infection in continuous ambulatory peritoneal dialysis. N Z Med J. 1996;109(1016):59.

5. Uribarri J, Bottone EJ, London RD. Pasteurella multocida peritonitis: are peritoneal dialysis patients on cyclers at increased risk? Perit Dial Int. 1996; 16(6):648-9

6. Loghman-Adham M. Pasteurella multocida peritonitis in patients undergoing peritoneal dialysis. Pediatr Nephrol. 1997;11(3):353-4.

7. Joh J, Padmanabhan R, Bastani B. Pasteurella multocida peritonitis following cat bite of peritoneal dialysis tubing. With a brief review of the literature. Am J Nephrol. 1998;18(3):258-9.

8. Chadha V, Warady BA. Capnocytophaga canimorsus peritonitis in a pediatric peritoneal dialysis patient. Pediatr Nephrol. 1999;13(8):646-8.

9. Hamai $\mathrm{K}$, Imai H, Ohtani $\mathrm{H}$. Repeated cat-associated peritonitis in a patient on automated nocturnal intermittent peritoneal dialysis. Clin Exp Nephrol. 1999;1:59-61.

10. Van Langenhove G, Daelemans R, Zachee P, Lins RL. Pasteurella multocida as a rare cause of peritonitis in peritoneal dialysis. Nephron. 2000;85(3):283-4.

11. Campos A, Taylor JH, Campbell M. Hamster bite peritonitis: Pasteurella pneumotropica peritonitis in a dialysis patient. Pediatr Nephrol. 2000; 15(1-2):31-2.

12. Freeman AF, Zheng XT, Lane JC, Shulman ST. Pasteurella aerogenes hamster bite peritonitis. Pediatr Infect Dis J. 2004;23(4):368-70.

13. Mat O, Moenens F, Beauwens R, Rossi C, Muniz-Martinez MC, Mestrez F, et al. Indolent Pasteurella multocida peritonitis in a CCPD patient. 25 years of "cat-bite peritonitis": a review. Perit Dial Int. 2005;25(1):88-90.

14. Malik A, Al Aly Z, Mailey KS, Bastani B. Pasteurella multocida peritoneal dialysis-associated peritonitis: a report of two cases and review of the literature. J Nephrol. 2005;18(6):791-3.

15. Sedlacek M, Cotter JG, Suriawinata AA, Kaneko TM, Zuckerman RA, Parsonnet J, et al. Mucormycosis peritonitis: more than 2 years of diseasefree follow-up after posaconazole salvage therapy after failure of liposomal amphotericin B. Am J Kidney Dis. 2008;51(2):302-6.

16. Rondon-Berrios H, Trevejo-Nunez GJ. Pets or pest: peritoneal dialysis-related peritonitis due to Pasteurella multocida. J Microbiol Immunol Infect. 2010; 43(2): 155-8

17. Nishina $M$, Yanagi $H$, Koizumi $M$, Kimura $M$, Kakuta $T$, Endoh $M$, et al. Pasteurella multocida peritonitis associated with a cat in a peritoneal dialysis patient using an automated cycler device. CEN Case Rep. 2012; 1(2):73-6. 
18. Giron FF, Martin JMS, Gomez ER, Munoz SC, Carmelo FG, Gomez IG, et al. Simultaneous Streptococcus canis and Pasteurella multocida peritonitis in a peritoneal dialysis patient. Perit Dial Int. 2017;37(4):483-4.

19. Broughton A, Verger C, Goffin E. Pets-related peritonitis in peritoneal dialysis: companion animals or trojan horses? Semin Dial. 2010;23(3):306-16.

20. Boseret G, Losson B, Mainil JG, Thiry E, Saegerman C. Zoonoses in pet birds: review and perspectives. Vet Res. 2013;44:36.

21. Poliquin PG, Lagace-Wiens P, Verrelli M, Allen DW, Embil JM. Pasteurella species peritoneal dialysis-associated peritonitis: household pets as a risk factor. Can J Infect Dis Med Microbiol. 2015;26(1):52-5.

22. Hogerwerf L, DEG B, Baan B, VDH W. Chlamydia psittaci (psittacosis) as a cause of community-acquired pneumonia: a systematic review and metaanalysis. Epidemiol Infect. 2017;145(15):3096-105.

23. Nosanchuk JD, Shoham S, Fries BC, Shapiro DS, Levitz SM, Casadevall A. Evidence of zoonotic transmission of Cryptococcus neoformans from a pet cockatoo to an immunocompromised patient. Ann Intern Med. 2000;132(3):205-8.

24. Greaves I, Kane K, Richards NT, Elliott TS, Adu D, Michael J. Pigeons and peritonitis? Nephrol Dial Transplant. 1992;7(9):967-9.

Ready to submit your research? Choose BMC and benefit from:

- fast, convenient online submission

- thorough peer review by experienced researchers in your field

- rapid publication on acceptance

- support for research data, including large and complex data types

- gold Open Access which fosters wider collaboration and increased citations

- maximum visibility for your research: over $100 \mathrm{M}$ website views per year

At $\mathrm{BMC}$, research is always in progress.

Learn more biomedcentral.com/submissions 